\title{
SEARCHING CORRELATIONS BETWEEN COMMUNICATION AND MOTIVATION
}

The aim of the paper is to examine various contents of the relations between communications (including informativeness), and motivation, i.e. consider the benefits of effective communication as well the risks of ineffective communication acting on motivation, perceive feedback as sustainable and accelerative element of any communication system, reflect on communication and informativeness as motivational tools, consider the need to motivate employees for quality communication and raising awareness in the organization and so on. The empirical part presents the most significant results of Slovak-Polish research in motivation regarding the linkages of informativeness, communication and motivation. Conclusion of the paper stresses the need to achieve a state in which effective communication will actually lead to permanent harmonizing all the motivations in the organization, i.e. all kinds of motives (individual, group and organizational) will be mutually harmonized.

Keywords: Communication, informativeness, motivation, survey, motives behind harmonization.

\section{Introduction}

Although people (in organizations) are communicating creatures, the language we use is not simply a means of communicating ideas. People express themselves to each other in symbolic form, and through verbal and non-verbal communication they create and shape relationships [1]. The importance of communication in organization is really great, e.g. from the viewpoint of building creativity [2 and 3], effectivity of education process [4], improving cooperation [5], affecting work behavior [6], increasing level of understandability [7], etc. Effective communication is the lifeblood of any organization [8] and the amount, nature, and uses of communication in the excellent organizations were remarkably different from those of their nonexcellent peers [9].

Many studies present there is a big difference between work expectations and needs that employees actually feel and how the managers foresee and interpret these needs of employees. Such a difference in perception may be due to just inoperable, impaired communication or incorrect interpretation of gained responses and requests from the employees and managers. For example, according to Tepper, most managers are convinced that their employees ranked first in their labor-motivational requirements particularly money and job security. However, many employees prefer a good job, recognition, a sense of belonging to the organization, and good working environment [10]. It follows that if organization management is based on misinterpretation of importance of their employees' motivational or other job preferences, i.e. if this one incorrectly draws conclusions from ongoing communication and sharing information, this one can adjust managerial mechanisms and activating documents in a false way. Incorrect knowledge bases on motivation and possible ways of motivating could potentially be dangerous, even fatal for the organization.

From mentioned reason, it is important to properly understand the motivation, its complexity, overall structure and, above all, its consequences for the organization. Motivation is the most dynamic, most changing, while most creative and destructive plethora of reasons, intentions, desires, and enhancers that characterize and elicit the behavior of individuals and groups. When defining it, for example, it is possible to focus attention on the positive and negative aspects. In this connection, Barret points out that people feel motivated, i.e. safe, secure, respected and happy when are able to meet their deficiency needs, but they feel anxious or fearful when they are prevented from meeting these needs or when the satisfaction of these needs is under threat [11]. Motivation has to be understood in all its complexity and varietal senses. According to Matuska, motivation is linked with biological standards of human organism, but also with spiritual and social side of human nature [12].

Communication in these experiential processes plays an important role, both in motivating and demotivating way. Based

\footnotetext{
* ${ }^{1}$ Martina Blaskova, ${ }^{1}$ Rudolf Blasko, ${ }^{2}$ Stanislaw Borkowski, ${ }^{2}$ Joanna Rosak-Szyrocka

${ }^{1}$ Faculty of Management Science and Informatics, University of Zilina, Slovakia

${ }^{2}$ Faculty of Management, Czestochowa University of Technology, Czestochowa, Poland

E-mail: blaskova@fri.uniza.sk
} 
on this, paper intent in the theoretical part is to examine various forms of connecting communication with motivation. The methodological part will present the most significant results of Slovak-Polish research on interdependence of communication (including informativeness) and motivation. Conclusion will stress the need to achieve a state in which the quality of communication and information will actually lead to permanent aligning all the motivations in the organization.

\section{Communication and informativeness in relation to motivation}

Communication participates in the creation and regulation of a subject's behavior in the way it directs the allocation of information because people communicate in order to receive data, or to exchange and modify it and, using such data, they perceive and can persuade thus potentially forming social ties [13]. According to Byers, communication is a symbolic process in which individuals exchange perceptions and ultimately build a knowledge bank for themselves and for others, for the purpose of shaping future actions [7]. It serves as an important channel of transferring and sharing information [14] and aims to understand and reduce uncertainty on both sides of the communication [15].

The relationship between the communication and awareness must be mutual. Employees and managers should communicate with each other in order to be mutually informed on future tasks, objectives, expected risks, results achieved and lessons learned, and able to utilize them even better. Vice-versa, members of the organization should be informed on how formal communication links are operating. It is needed to instill them the principle the informal communication links must always support the organization's vision and mission.

It is important because of, unfortunately, "informal spontaneous communication comes at a cost: interruption. Modern communication technologies have made communication more convenient but have also increased sources of interruption. Empirical research demonstrates the costs associated with interruptions in the workplace," [16]. This leads to knowledge we have to put emphasis on the necessity to remove unwished barriers, and strengthen the feedback in communication relations [17]. It means we have to respect the communication is a two-way process - it is about saying something, listening to the response, responding accordingly [6], waiting for and listening to the opinions and new suggestions from the side of communication partner, expressing strong interest in partner and his attitudes, etc.

It is necessary to very carefully pay attention to the nature of feedback. Feedback should be motivating, conducive. According to Barrett, people feel happiness when they get positive feedback when they are praised or acknowledged by someone they respect [11]. Feedback must not be hurtful because it could induce undesirable response in terms of decrease of performance, effort, belief, motivation, and willingness to engage in further processes. The unexpected benefit may be the feedback based on the de-encryption of nonverbal communication [18] or decoding meta-communication (hidden) messages [19, 20 and 21], which can detect malfunctioning communication, point to the specific errors in the communication systems of individuals and groups, and thus show that awareness in the organization is incomplete and fails to fulfill the role of necessary platform for the motivation and security.

In order to harmonize interconnection and potential benefits of informativeness, communication and high motivation, it is necessary to consider not only the abundance of quality information for employees but it is necessary to focus attention on the content and the difficulty of communicating on motivation. More specifically, the complexity of motivating lies in the fact the employees and managers are often unable to accurately define and express what constitutes their work motivation and what exactly they expect from the work - what will bring them the desired satisfaction. Content of primary and secondary motivational categories of each individual is unique and it is always a very special and personal and many individuals consider it to be sensible and do not like to present it to others. In addition, it is not easy to navigate absolutely perfectly in one's own motivation. Bedrnova, Nový et al. made similar comments: "Investigation of motivation is difficult. It is because man himself does not realize his motivation in all its complexity and complex structure and, therefore, often is unable to speak about it," [22].

The importance and seriousness of communication and informativeness in relation to the motivation must be considered also from the managerial viewpoint. "Communication serves to motivate; clarify duties, authority, and responsibilities; and permit the expression of feelings," [2]. Mayfield, Mayfield and Sharbrough [23], based on motivating language theory, point out that top leaders can construct and transmit strategic vision of communications for improving organizational performance. Motivating language has to include multilevel and external communication, and should be supported by a cybernetic feedback process.

When considering communication from the viewpoint of an organizational culture, culture encourages the cooperation and effective mutual communication across the organization [24] which strengthens the motivation. Through communication we are comforted and feel empathy from others; but on the other hand, through communication we are hurt, abused and trivialized by others [1]. It means, communication has both positive and negative impacts on the motivation, and thus, it must be carefully performed and mixed.

From the positive viewpoint, open and motivating communication by the management structure of the organization and thorough informativeness might be understood as the effective motivational tools. According to Figurska, reciprocal information is an essential factor of motivation. Employees must 
have truthful information regarding their duties and the content of their role in achieving the objectives and their impact on organizational success. They must therefore obtain information on the organization as well emerging chances, and threats [25]. It is also important to ensure not only enough information but also the sufficient diversity and objective credibility of it. The creative employees should have information derived from primary and secondary sources: books, journals, reports, specifications and norms, rules of procedures, laws and decrees, professional literature, internal reports, etc. [3].

When connecting informativeness with the self-motivation, an idea has to be also mentioned: The self-improvement motive leads people to "improve their traits, abilities, skills, health status, or well-being" [26]. This motivates seeking genuine improvement and personal growth. The motive is inferred from behaviors such as actively approaching and coping with problems, seeking information that enables improvement, practicing existing skills, and choosing to work on remedial tasks that reduce deficiencies [27].

However, in order for the communication-informational motivators to be able to discharge their potency in depth, it is necessary to allow employees and managers to be able to communicate openly, without fear or embarrassment when their ideas considered will not be perfect, or without fear of sanctions when the information concerned warnings on the inefficiencies in the organization. Frankel points out that comments and suggestions from anyone within and without the organization should be encouraged and given serious consideration no matter from which level or individual they originate and how critical they may be. ... Employee suggestions and involvement must be recognized and rewarded [8, p. 14].

Compared with easier understandable verbal communicating, the importance of nonverbal communication more and more increases at present. Non-verbal channels such as nodding head, encouraging glance and other gesture serve as an illustration to enhance people's speech or argument [28, 18 and 20]. Employees and managers use such illustrators to emphasize their message more effectively [14]. However, great vigilance must prevail in the use of nonverbal communication channels. Positive non-verbal communication (smile communication, closeness, encouraging touch, etc.) can significantly strengthen the motivation. It can enhance the veracity of the claims and overall cultivation of performed communication. On the other hand, negative nonverbal communication (aggressive voice, frown or haughty view, posture full of negative power, etc.) can be very harmful to motivation.

\section{Method}

Based on mentioned above assumptions, we decided to confirm assumption in our survey that there exists a significant dependency of level/quality of communication (and awareness/ informativeness) and the level of motivation. In addition, we assume the comparison of results between Polish and Slovak respondents - residents of the two Slavic countries - could generate more interesting inspirations for the more advanced motivating.

In terms of the survey efficiency undertaken in conditions of two countries, we decided to use the method of a sociological questioning, performed through a technique of questionnaire. In total, 3,682 respondents $(1,946=52.85 \%$ from Slovakia and $1,736=47.15 \%$ from Poland) with an average age of 37.50 years participated in the survey. There were $1,845(50.11 \%)$ males and 1,837 (49.89\%) females. More detailed identifiers of respondents are indicated in Table 1. When processing and evaluating respondents expressions in questionnaires we used our own program, created on the platform of database systems.

Firstly, we investigated whether the respondents considered themselves to be sufficiently informed on the objectives and problems of their workplace and the organization and whether they consider the communication performed towards them as an open and effective. To evaluate these issues, Likert 5-point scale was chosen where respondents could choose from the following answers: 1 not; 2 - mostly not; 3 - average; 4 - mostly yes; 5 - yes. To meet the needs of a significant evaluation, we structured these answers into the following three categories: no (level $1+2$ ); sometimes

Identification of respondents in the Slovak Republic and Poland (total and percentage)

Table 1

\begin{tabular}{|c|c|c|c|c|c|c|c|c|c|c|c|c|c|}
\hline & \multicolumn{6}{|c|}{ Slovak Republic $(1,946=100 \%)$} & \multicolumn{7}{|c|}{ Poland $(1,736=100 \%)$} \\
\hline \multirow{2}{*}{ Sex/gender } & \multicolumn{3}{|c|}{ Males } & \multicolumn{3}{|c|}{ Females } & \multicolumn{4}{|c|}{ Males } & \multicolumn{3}{|c|}{ Females } \\
\hline & \multicolumn{3}{|c|}{$839 \quad 43.11 \%$} & \multicolumn{3}{|c|}{$1.107 \quad 56.89 \%$} & \multicolumn{4}{|c|}{$57.96 \%$} & \multicolumn{3}{|c|}{$730 \quad 42.05 \%$} \\
\hline \multirow{2}{*}{ Age in years } & $17-25$ & \multicolumn{2}{|c|}{$26-35$} & \multicolumn{2}{|c|}{$36-45$} & $46-68$ & & -25 & \multicolumn{2}{|c|}{ 26-35 } & \multicolumn{2}{|c|}{$36-45$} & $46-68$ \\
\hline & $239 \quad 12.28 \%$ & 585 & $30.06 \%$ & 546 & $28.06 \%$ & $576 \quad 29.60 \%$ & 249 & $14.34 \%$ & 647 & $37.27 \%$ & $515 \quad 2$ & $9.67 \%$ & $325 \quad 18.72 \%$ \\
\hline \multirow{2}{*}{$\begin{array}{l}\text { Practice } \\
\text { in years }\end{array}$} & $0-5$ & \multicolumn{2}{|c|}{$6-15$} & \multicolumn{2}{|c|}{$16-25$} & $26-50$ & & -5 & \multicolumn{2}{|c|}{$6-15$} & \multicolumn{2}{|c|}{$16-25$} & $26-50$ \\
\hline & $439 \quad 22.56 \%$ & 550 & $28.26 \%$ & 515 & $26.46 \%$ & $442 \quad 22.71 \%$ & 620 & $35.71 \%$ & 649 & $37.38 \%$ & 293 & $16.88 \%$ & $174 \quad 10.02 \%$ \\
\hline \multirow{2}{*}{ Education } & \multicolumn{2}{|c|}{ Secondary } & \multicolumn{2}{|c|}{ College } & \multicolumn{2}{|r|}{ PhD. } & \multicolumn{3}{|c|}{ Secondary } & \multicolumn{2}{|c|}{ College } & \multicolumn{2}{|r|}{ PhD. } \\
\hline & 1.166 & & 757 & $38.90 \%$ & & $231.18 \%$ & 1.0 & 61 & & 634 & $36.52 \%$ & & $2.36 \%$ \\
\hline
\end{tabular}


Answers of respondents about their informativeness and communication openness

Table 2

\begin{tabular}{|c|c|c|c|c|c|c|c|c|c|}
\hline \multirow{3}{*}{ Answers scale } & \multicolumn{3}{|c|}{ All $(\mathrm{N}=3,682)$} & \multicolumn{3}{|c|}{ Slovak respondents $(\mathrm{N}=1,946)$} & \multicolumn{3}{|c|}{ Polish respondents $(\mathrm{N}=1,736)$} \\
\hline & All & Male & Female & All & Male & Female & All & Male & Female \\
\hline & $\begin{array}{c}3,682 \\
100.00 \%\end{array}$ & $\begin{array}{c}1,845 \\
100.00 \%\end{array}$ & $\begin{array}{c}1,837 \\
100.00 \%\end{array}$ & $\begin{array}{c}1,946 \\
100.00 \%\end{array}$ & $\begin{array}{c}839 \\
100.00 \%\end{array}$ & $\begin{array}{c}1,107 \\
100.00 \%\end{array}$ & $\begin{array}{c}1,736 \\
100.00 \%\end{array}$ & $\begin{array}{c}1,006 \\
100.00 \%\end{array}$ & $\begin{array}{c}730 \\
100.00 \%\end{array}$ \\
\hline & \multicolumn{9}{|c|}{ Level of informativeness } \\
\hline No [1-2] & $7.44 \%$ & $6.29 \%$ & $8.60 \%$ & $8.17 \%$ & $5.36 \%$ & $10.30 \%$ & $6.62 \%$ & $7.06 \%$ & $6.03 \%$ \\
\hline Average [3] & $18.52 \%$ & $17.67 \%$ & $19.38 \%$ & $19.48 \%$ & $17.88 \%$ & $20.69 \%$ & $17.45 \%$ & $17.50 \%$ & $17.40 \%$ \\
\hline Yes [4-5] & $74.04 \%$ & $76.04 \%$ & $72.02 \%$ & $72.35 \%$ & $76.76 \%$ & $69.02 \%$ & $75.92 \%$ & $75.45 \%$ & $76.58 \%$ \\
\hline Mean & 3.94 & 3.99 & 3.90 & 3.89 & 4.00 & 3.81 & 4.00 & 3.98 & 4.03 \\
\hline \multicolumn{10}{|c|}{ Openness and efficiency of communication } \\
\hline No [1-2] & $7.17 \%$ & $6.29 \%$ & $8.06 \%$ & $8.07 \%$ & $6.56 \%$ & $9.21 \%$ & $6.16 \%$ & $6.06 \%$ & $6.30 \%$ \\
\hline Average [3] & $23.09 \%$ & $22.60 \%$ & $23.57 \%$ & $24.05 \%$ & $22.05 \%$ & $25.56 \%$ & $22.00 \%$ & $23.06 \%$ & $20.55 \%$ \\
\hline Yes [4-5] & $69.74 \%$ & $71.11 \%$ & $68.37 \%$ & $67.88 \%$ & $71.39 \%$ & $65.22 \%$ & $71.83 \%$ & $70.87 \%$ & $73.15 \%$ \\
\hline Mean & 3.86 & 3.89 & 3.83 & 3.82 & 3.87 & 3.78 & 3.90 & 3.90 & 3.91 \\
\hline
\end{tabular}

Answers of respondents about the motivation level to basic areas of work behavior

Table 3

\begin{tabular}{|c|c|c|c|c|c|c|c|c|c|}
\hline \multirow{3}{*}{ Answers scale } & \multicolumn{3}{|c|}{ All $(\mathrm{N}=3,682)$} & \multicolumn{3}{|c|}{ Slovak respondents $(\mathrm{N}=1,946)$} & \multicolumn{3}{|c|}{ Polish respondents $(\mathrm{N}=1,736)$} \\
\hline & All & Male & Female & All & Male & Female & All & Male & Female \\
\hline & $\begin{array}{c}3,682 \\
100.00 \%\end{array}$ & $\begin{array}{c}1,845 \\
100.00 \%\end{array}$ & $\begin{array}{c}1,837 \\
100.00 \%\end{array}$ & $\begin{array}{c}1,946 \\
100.00 \%\end{array}$ & $\begin{array}{c}839 \\
100.00 \%\end{array}$ & $\begin{array}{c}1,107 \\
100.00 \%\end{array}$ & $\begin{array}{c}1,736 \\
100.00 \%\end{array}$ & $\begin{array}{c}1,006 \\
100.00 \%\end{array}$ & $\begin{array}{c}730 \\
100.00 \%\end{array}$ \\
\hline & \multicolumn{9}{|c|}{ Level of motivation } \\
\hline & \multicolumn{9}{|c|}{ a) to quality of work } \\
\hline Low [1-2] & $4.10 \%$ & $4.01 \%$ & $4.19 \%$ & $4.32 \%$ & $4.77 \%$ & $3.97 \%$ & $3.86 \%$ & $3.38 \%$ & $4.52 \%$ \\
\hline Average [3] & $22.32 \%$ & $22.60 \%$ & $22.05 \%$ & $21.17 \%$ & $19.43 \%$ & $22.49 \%$ & $23.62 \%$ & $25.25 \%$ & $21.37 \%$ \\
\hline High [4-5] & $73.57 \%$ & $73.39 \%$ & $73.76 \%$ & $74.51 \%$ & $75.80 \%$ & $73.53 \%$ & $72.52 \%$ & $71.37 \%$ & $74.11 \%$ \\
\hline \multirow[t]{2}{*}{ Mean } & 3.91 & 3.92 & 3.91 & 3.92 & 3.95 & 3.90 & 3.91 & 3.89 & 3.93 \\
\hline & \multicolumn{9}{|c|}{ b) to the increase of knowledge and skills } \\
\hline Low [1-2] & $6.49 \%$ & $6.18 \%$ & $6.80 \%$ & $7.55 \%$ & $7.99 \%$ & $7.23 \%$ & $5.30 \%$ & $4.67 \%$ & $6.16 \%$ \\
\hline Average [3] & $29.11 \%$ & $29.05 \%$ & $29.18 \%$ & $30.06 \%$ & $27.41 \%$ & $32.07 \%$ & $28.05 \%$ & $30.42 \%$ & $24.79 \%$ \\
\hline High [4-5] & $64.39 \%$ & $64.77 \%$ & $64.02 \%$ & $62.38 \%$ & $64.60 \%$ & $60.70 \%$ & $66.65 \%$ & $64.91 \%$ & $69.04 \%$ \\
\hline \multirow[t]{2}{*}{ Mean } & 3.73 & 3.73 & 3.73 & 3.69 & 3.72 & 3.66 & 3.78 & 3.75 & 3.83 \\
\hline & \multicolumn{9}{|c|}{ c) to new suggestions } \\
\hline Low [1-2] & $9.70 \%$ & $9.43 \%$ & $9.96 \%$ & $11.25 \%$ & $11.08 \%$ & $11.38 \%$ & $7.95 \%$ & $8.05 \%$ & $7.81 \%$ \\
\hline Average [3] & $37.24 \%$ & $35.50 \%$ & $38.98 \%$ & $41.78 \%$ & $37.54 \%$ & $44.99 \%$ & $32.14 \%$ & $33.80 \%$ & $29.86 \%$ \\
\hline High [4-5] & $53.07 \%$ & $55.07 \%$ & $51.06 \%$ & $46.97 \%$ & $51.37 \%$ & $43.63 \%$ & $59.91 \%$ & $58.15 \%$ & $62.33 \%$ \\
\hline \multirow[t]{2}{*}{ Mean } & 3.53 & 3.56 & 3.49 & 3.42 & 3.51 & 3.36 & 3.65 & 3.61 & 3.70 \\
\hline & \multicolumn{9}{|c|}{ d) to cooperation with superior } \\
\hline Low [1-2] & $10.92 \%$ & $11.06 \%$ & $10.78 \%$ & $11.10 \%$ & $11.20 \%$ & $11.02 \%$ & $10.71 \%$ & $10.93 \%$ & $10.41 \%$ \\
\hline Average [3] & $36.61 \%$ & $35.61 \%$ & $37.62 \%$ & $37.51 \%$ & $34.68 \%$ & $39.66 \%$ & $35.60 \%$ & $36.38 \%$ & $34.52 \%$ \\
\hline High [4-5] & $52.47 \%$ & $53.33 \%$ & $51.61 \%$ & $51.39 \%$ & $54.11 \%$ & $49.32 \%$ & $53.69 \%$ & $52.68 \%$ & $55.07 \%$ \\
\hline Mean & 3.50 & 3.51 & 3.49 & 3.48 & 3.53 & 3.44 & 3.52 & 3.50 & 3.56 \\
\hline
\end{tabular}

(level 3); yes (level $4+5$ ). Table 2 shows the percentage of relative evaluation of individual response categories, as well as average value (mean) of achieved response level (on a scale 1 - 5). Almost a third of respondents consider their degree of awareness and quality of communication only as average or even insufficient. When examining communication openness, answers of Slovak women were on average lower than the value of Slovak men (in Poland it was almost balanced). When comparing between the 
two countries, the results of Slovak respondents were slightly worse than Polish. Medians for all groups were 4.00; upper quantiles were 4.00 or 5.00 .

In a next question we examined the level (strength) of motivation. Respondents were asked to tag the strength of their motivation: a) to quality of work; b) to increase their knowledge and skills; c) to submission of new ideas; d) to cooperate with superiors. We also used a Likert five-level scale, with following specific content of the replies: 1 - low motivation; 2 - rather lower; 3 - average; 4 - rather higher; 5 - high. We subsequently merged responses into these three categories: low (level $1+2$ ); average (level 3); high (level $4+5$ ). The results in Table 3 show the respondents feel the highest motivation to the quality of their work.

The average values of motivations were again higher in the case of Polish respondents. This implies that, like the area

Results in searching dependency between level of informativeness and level of motivation

Table 4

\begin{tabular}{|c|c|c|c|c|c|c|c|c|c|}
\hline \multirow{4}{*}{$\begin{array}{c}\text { Motivation } \\
\text { level/ } \\
\text { Information } \\
\text { Level }\end{array}$} & \multicolumn{3}{|c|}{ All $(\mathrm{N}=3,682)$} & \multicolumn{3}{|c|}{ Slovak respondents $(\mathrm{N}=1,946)$} & \multicolumn{3}{|c|}{ Polish respondents $(\mathrm{N}=1,736)$} \\
\hline & Yes $[4+5]$ & Average [3] & No $[1+2]$ & Yes $[4+5]$ & Average [3] & No $[1+2]$ & Yes $[4+5]$ & Average [3] & No [1+2] \\
\hline & $\begin{array}{c}2,726 \\
100.00 \%\end{array}$ & $\begin{array}{c}682 \\
100.00 \%\end{array}$ & $\begin{array}{c}274 \\
100.00 \%\end{array}$ & $\begin{array}{c}1,408 \\
100.00 \%\end{array}$ & $\begin{array}{c}379 \\
100.00 \%\end{array}$ & $\begin{array}{c}159 \\
100.00 \%\end{array}$ & $\begin{array}{c}1,318 \\
100.00 \%\end{array}$ & $\begin{array}{c}303 \\
100.00 \%\end{array}$ & $\begin{array}{c}115 \\
100.00 \%\end{array}$ \\
\hline & \multicolumn{9}{|c|}{ a) Motivation to quality of work } \\
\hline Low [1-2] & $2.16 \%$ & $6.30 \%$ & $17.88 \%$ & $2.63 \%$ & $6.60 \%$ & $13.84 \%$ & $1.67 \%$ & $5.94 \%$ & $23.48 \%$ \\
\hline Average [3] & $17.57 \%$ & $37.24 \%$ & $32.48 \%$ & $16.48 \%$ & $34.56 \%$ & $30.82 \%$ & $18.74 \%$ & $40.59 \%$ & $34.78 \%$ \\
\hline High [4-5] & $80.26 \%$ & $56.45 \%$ & $49.64 \%$ & $80.89 \%$ & $58.84 \%$ & $55.35 \%$ & $79.59 \%$ & $53.47 \%$ & $41.74 \%$ \\
\hline $\operatorname{High} \pi$ & $77.26 \%$ & $49.45 \%$ & $38.64 \%$ & $76.89 \%$ & $49.84 \%$ & $41.35 \%$ & $64.59 \%$ & $43.47 \%$ & $26.74 \%$ \\
\hline Mean & 4.05 & 3.60 & 3.39 & 4.04 & 3.65 & 3.51 & 4.05 & 3.55 & 3.23 \\
\hline Median & 4.00 & 4.00 & 3.00 & 4.00 & 4.00 & 4.00 & 4.00 & 4.00 & 3.00 \\
\hline \multirow[t]{2}{*}{ Std deviation } & 0.75 & 0.81 & 1.14 & 0.75 & 0.83 & 1.08 & 0.75 & 0.79 & 1.19 \\
\hline & \multicolumn{9}{|c|}{ b) Motivation to the increase of knowledge and skills } \\
\hline Low [1-2] & $3.85 \%$ & $11.73 \%$ & $19.71 \%$ & $4.47 \%$ & $14.51 \%$ & $18.24 \%$ & $3.19 \%$ & $8.25 \%$ & $21.74 \%$ \\
\hline Average [3] & $25.02 \%$ & $43.11 \%$ & $35.04 \%$ & $26.70 \%$ & $39.05 \%$ & $38.36 \%$ & $23.22 \%$ & $48.18 \%$ & $30.43 \%$ \\
\hline High [4-5] & $71.13 \%$ & $45.16 \%$ & $45.26 \%$ & $68.82 \%$ & $46.44 \%$ & $43.40 \%$ & $73.60 \%$ & $43.56 \%$ & $47.83 \%$ \\
\hline High $\pi$ & $67.13 \%$ & $38.16 \%$ & $34.26 \%$ & $63.82 \%$ & $37.44 \%$ & $30.40 \%$ & $68.60 \%$ & $33.56 \%$ & $31.83 \%$ \\
\hline Mean & 3.85 & 3.41 & 3.35 & 3.80 & 3.40 & 3.33 & 3.90 & 3.42 & 3.37 \\
\hline Median & 4.00 & 3.00 & 3.00 & 4.00 & 3.00 & 3.00 & 4.00 & 3.00 & 3.00 \\
\hline \multirow[t]{2}{*}{ Std deviation } & 0.78 & 0.88 & 1.14 & 0.79 & 0.93 & 1.06 & 0.76 & 0.82 & 1.23 \\
\hline & \multicolumn{9}{|c|}{ c) Motivation to new suggestions } \\
\hline Low [1-2] & $6.31 \%$ & $17.01 \%$ & $25.18 \%$ & $7.17 \%$ & $20.84 \%$ & $24.53 \%$ & $5.39 \%$ & $12.21 \%$ & $26.09 \%$ \\
\hline Average [3] & $34.19 \%$ & $48.39 \%$ & $39.78 \%$ & $38.85 \%$ & $51.19 \%$ & $45.28 \%$ & $29.21 \%$ & $44.88 \%$ & $32.17 \%$ \\
\hline High [4-5] & $59.50 \%$ & $34.60 \%$ & $35.04 \%$ & $53.98 \%$ & $27.97 \%$ & $30.19 \%$ & $65.40 \%$ & $42.90 \%$ & $41.74 \%$ \\
\hline High $\pi$ & $55.50 \%$ & $27.60 \%$ & $25.04 \%$ & $48.98 \%$ & $19.97 \%$ & $19.19 \%$ & $60.40 \%$ & $32.90 \%$ & $26.74 \%$ \\
\hline Mean & 3.65 & 3.20 & 3.11 & 3.56 & 3.06 & 3.04 & 3.75 & 3.37 & 3.21 \\
\hline Median & 4.00 & 3.00 & 3.00 & 4.00 & 3.00 & 3.00 & 4.00 & 3.00 & 3.00 \\
\hline \multirow[t]{2}{*}{ Std deviation } & 0.83 & 0.89 & 1.10 & 0.82 & 0.87 & 1.03 & 0.82 & 0.87 & 1.19 \\
\hline & \multicolumn{9}{|c|}{ d) Motivation to cooperation with superior } \\
\hline Low [1-2] & $7.45 \%$ & $17.16 \%$ & $29.93 \%$ & $7.46 \%$ & $16.36 \%$ & $30.82 \%$ & $7.44 \%$ & $18.15 \%$ & $28.70 \%$ \\
\hline Average [3] & $32.72 \%$ & $49.27 \%$ & $43.80 \%$ & $32.53 \%$ & $51.19 \%$ & $49.06 \%$ & $32.93 \%$ & $46.86 \%$ & $36.52 \%$ \\
\hline High [4-5] & $59.83 \%$ & $33.58 \%$ & $26.28 \%$ & $60.01 \%$ & $32.45 \%$ & $20.13 \%$ & $59.64 \%$ & $34.98 \%$ & $34.78 \%$ \\
\hline $\operatorname{High} \pi$ & $55.83 \%$ & $27.58 \%$ & $17.28 \%$ & 55.01 & $26.45 \%$ & $11.13 \%$ & $54.64 \%$ & $25.98 \%$ & $20.78 \%$ \\
\hline Mean & 3.64 & 3.17 & 2.90 & 3.64 & 3.16 & 2.77 & 3.64 & 3.18 & 3.08 \\
\hline Median & 4.00 & 3.00 & 3.00 & 4.00 & 3.00 & 3.00 & 4.00 & 3.00 & 3.00 \\
\hline Std deviation & 0.84 & 0.88 & 1.07 & 0.84 & 0.89 & 0.96 & 0.85 & 0.88 & 1.19 \\
\hline
\end{tabular}


of information and communication quality, also the area of motivation in Slovakia has more significant reserves than in Poland. In terms of gender differences, Slovak women expressed higher motivation versus Slovak men for all the motivational orientations. This leads to recommendation to much more improve and intensify the motivational efforts against the women in Slovakia. In contrast, the average values of Polish women's motivation were higher than those of Polish men's.
A key concern of our survey was to determine whether the level of information and quality of communication can be considered as dependent in relation to the strength of motivation. As appears from Tables 4 and 5, our assumption was confirmed: all the motivations are declining with the decreasing awareness and communication. This means the lower the quality of informativeness and communication, the lower the motivation. If respondents are informed or communication is open, their motivation is approximately $25 \%$ higher. This changes neither in

Results in searching dependency between openness of communication and level of motivation

Table 5

\begin{tabular}{|c|c|c|c|c|c|c|c|c|c|}
\hline \multirow{4}{*}{$\begin{array}{l}\text { Motivation } \\
\text { level/ } \\
\text { Communi- } \\
\text { cation level }\end{array}$} & \multicolumn{3}{|c|}{ All $(\mathrm{N}=3,682)$} & \multicolumn{3}{|c|}{ Slovak respondents $(N=1,946)$} & \multicolumn{3}{|c|}{ Polish respondents $(\mathrm{N}=1,736)$} \\
\hline & Yes $[4+5]$ & Average [3] & No [1+2] & Yes $[4+5]$ & Average [3] & No [1+2] & Yes $[4+5]$ & Average [3] & No [1+2] \\
\hline & $\begin{array}{c}2,568 \\
100.00 \%\end{array}$ & $\begin{array}{c}850 \\
100.00 \%\end{array}$ & $\begin{array}{c}264 \\
100.00 \%\end{array}$ & $\begin{array}{c}1,321 \\
100.00 \%\end{array}$ & $\begin{array}{c}468 \\
100.00 \%\end{array}$ & $\begin{array}{c}157 \\
100.00 \%\end{array}$ & $\begin{array}{c}1,247 \\
100.00 \%\end{array}$ & $\begin{array}{c}382 \\
100.00 \%\end{array}$ & $\begin{array}{c}107 \\
100.00 \%\end{array}$ \\
\hline & \multicolumn{9}{|c|}{ a) Motivation to quality of work } \\
\hline Low [1-2] & $1.48 \%$ & $4.82 \%$ & $27.27 \%$ & $1.97 \%$ & $6.20 \%$ & $18.47 \%$ & $0.96 \%$ & $3.14 \%$ & $40.19 \%$ \\
\hline Average [3] & $16.74 \%$ & $36.94 \%$ & $29.55 \%$ & $17.18 \%$ & $30.56 \%$ & $26.75 \%$ & $16.28 \%$ & $44.76 \%$ & $33.64 \%$ \\
\hline High [4-5] & $81.78 \%$ & $58.24 \%$ & $43.18 \%$ & $80.85 \%$ & $63.25 \%$ & $54.78 \%$ & $82.76 \%$ & $52.09 \%$ & $26.17 \%$ \\
\hline High $\pi$ & $78.78 \%$ & $52.24 \%$ & $32.18 \%$ & $75.85 \%$ & $54.25 \%$ & $40.78 \%$ & $77.76 \%$ & $43.09 \%$ & $14.17 \%$ \\
\hline Mean & 4.08 & 3.65 & 3.18 & 4.05 & 3.72 & 3.46 & 4.11 & 3.55 & 2.77 \\
\hline Median & 4.00 & 4.00 & 3.00 & 4.00 & 4.00 & 4.00 & 4.00 & 4.00 & 3.00 \\
\hline \multirow[t]{2}{*}{ Std deviation } & 0.72 & 0.80 & 1.19 & 0.73 & 0.85 & 1.13 & 0.71 & 0.73 & 1.16 \\
\hline & \multicolumn{9}{|c|}{ b) Motivation to the increase of knowledge and skills } \\
\hline Low [1-2] & $3.62 \%$ & $9.76 \%$ & $23.86 \%$ & $4.92 \%$ & $11.97 \%$ & $16.56 \%$ & $2.25 \%$ & $7.07 \%$ & $34.58 \%$ \\
\hline Average [3] & $23.99 \%$ & $42.82 \%$ & $34.85 \%$ & $26.42 \%$ & $38.46 \%$ & $35.67 \%$ & $21.41 \%$ & $48.17 \%$ & $33.64 \%$ \\
\hline High [4-5] & $72.39 \%$ & $47.41 \%$ & $41.29 \%$ & $68.66 \%$ & $49.57 \%$ & $47.77 \%$ & $76.34 \%$ & $44.76 \%$ & $31.78 \%$ \\
\hline High $\pi$ & $68.39 \%$ & $41.41 \%$ & $31.29 \%$ & $63.66 \%$ & $41.57 \%$ & $33.77 \%$ & $71.34 \%$ & $35.76 \%$ & $17.78 \%$ \\
\hline Mean & 3.88 & 3.46 & 3.17 & 3.80 & 3.47 & 3.34 & 3.96 & 3.44 & 2.93 \\
\hline Median & 4.00 & 3.00 & 3.00 & 4.00 & 3.00 & 3.00 & 4.00 & 3.00 & 3.00 \\
\hline \multirow[t]{2}{*}{ Std deviation } & 0.78 & 0.85 & 1.11 & 0.81 & 0.90 & 1.00 & 0.74 & 0.78 & 1.21 \\
\hline & \multicolumn{9}{|c|}{ c) Motivation to new suggestions } \\
\hline Low [1-2] & $5.72 \%$ & $14.35 \%$ & $33.33 \%$ & $6.66 \%$ & $18.16 \%$ & $29.30 \%$ & $4.73 \%$ & $9.69 \%$ & $39.25 \%$ \\
\hline Average [3] & $32.79 \%$ & $51.06 \%$ & $35.98 \%$ & $39.06 \%$ & $50.64 \%$ & $38.22 \%$ & $26.14 \%$ & $51.57 \%$ & $32.71 \%$ \\
\hline High [4-5] & $61.49 \%$ & $34.59 \%$ & $30.68 \%$ & $54.28 \%$ & $31.20 \%$ & $32.48 \%$ & $69.13 \%$ & $38.74 \%$ & $28.04 \%$ \\
\hline High $\pi$ & $57.49 \%$ & $28.59 \%$ & $21.68 \%$ & $49.28 \%$ & $24.20 \%$ & $20.48 \%$ & $64.13 \%$ & $29.74 \%$ & $15.04 \%$ \\
\hline Mean & 3.69 & 3.22 & 2.90 & 3.58 & 3.14 & 2.96 & 3.82 & 3.32 & 2.81 \\
\hline Median & 4.00 & 3.00 & 3.00 & 4.00 & 3.00 & 3.00 & 4.00 & 3.00 & 3.00 \\
\hline \multirow[t]{2}{*}{ Std deviation } & 0.81 & 0.83 & 1.18 & 0.81 & 0.87 & 1.12 & 0.79 & 0.77 & 1.26 \\
\hline & \multicolumn{9}{|c|}{ d) Motivation to cooperation with superior } \\
\hline Low [1-2] & $5.72 \%$ & $17.18 \%$ & $41.29 \%$ & $5.00 \%$ & $19.23 \%$ & $38.22 \%$ & $6.50 \%$ & $14.66 \%$ & $45.79 \%$ \\
\hline Average [3] & $31.31 \%$ & $52.12 \%$ & $38.26 \%$ & $32.02 \%$ & $51.71 \%$ & $41.40 \%$ & $30.55 \%$ & $52.62 \%$ & $33.64 \%$ \\
\hline High [4-5] & $62.97 \%$ & $30.71 \%$ & $20.45 \%$ & $62.98 \%$ & $29.06 \%$ & $20.38 \%$ & $62.95 \%$ & $32.72 \%$ & $20.56 \%$ \\
\hline High $\pi$ & $59.97 \%$ & $24.71 \%$ & $12.45 \%$ & $57.98 \%$ & $22.06 \%$ & $11.38 \%$ & $57.95 \%$ & $24.72 \%$ & $9.56 \%$ \\
\hline Mean & 3.70 & 3.14 & 2.67 & 3.71 & 3.09 & 2.67 & 3.70 & 3.20 & 2.66 \\
\hline Median & 4.00 & 3.00 & 3.00 & 4.00 & 3.00 & 3.00 & 4.00 & 3.00 & 3.00 \\
\hline Std deviation & 0.81 & 0.85 & 1.13 & 0.79 & 0.84 & 1.10 & 0.83 & 0.86 & 1.17 \\
\hline
\end{tabular}


terms of gender, nor age, nor experience, nor education (although it is true that the higher the education, the higher motivation).

We searched the null hypothesis H0: "The probability, that the informativeness, respectively communication level in a given level of motivation is high, is equal to $\pi$ " and an alternative hypothesis H1: "The considered probability is less than the $\pi$." Test with parameter $\pi$ of an alternative distribution was chosen for testing, where an unknown probability of $\pi$ is estimated through using the relative frequency $p$ of the phenomenon occurrence (informativeness/communication is high) - i.e. their number is divided by the number of choice. Tested criterion has a format, where $\pi$ is the estimated probability, $p$ is the relative frequency of respondents who said their informativeness/communication level is high (i.e. grades $4-5$, that is rather higher and high). The value of $\pi$ (High $\pi$ in Table 4 and 5) is the lowest just such that level of significance $\alpha$, at which the hypothesis $\mathrm{H} 0$ is not rejected, was $\alpha<0.05$.

When considering the communication quality, the differences are even greater and the average values decrease. Major differences are visible in the case of Polish respondents.

\section{Conclusion}

As follows from our survey, communication and informativeness have undeniable and extremely strong ties to motivation. Just their accuracy, frequency, clarity and willingness can have a major impact on the quality, orientation, and sustainability of the organization members' motivation. The problem of sophistication of the communication arises forcefully: communication must be decent, carried out perfectly and directed positively. It should be focused on inducing positive impressions, voluntary admission of high responsibility and enthusiasm for the joint metes and challenges. An active togetherness of verbal and nonverbal communication appears to have possible contribution. Verbal communication puts emphasis, accent, and necessity. Smile communication, identical physical and habit emblems, squeezing a mutual distance, empathy, etc., give depth, a sense of reciprocity, support, dignity, and mutual esteem. Just such communication convinces the motivation.

In addition, the content and possibilities of motivational program of organization should be intentionally communicated to all employees and managers. Based on understanding the organizational motivation program, the managers can create appropriate sectional and individualized programs for their employees. Employees must know what their growth opportunities and prospects in organization are, what profits could be earned in return for extra work. They must know they are highly valued for their manager.
Based on our survey results, it is appropriate to activate interdependence between quality of communication and quality of motivation. This means communication must also be about the need to constantly update and dynamize all types of motivation programs within the organization. The necessity of proactive changes and culture of high performance should be implanted into the behavior of the organization members. This necessity has to be built on a high level of understanding, fellowship, and sharing views on processes and efficiency within the organization. In this situation, it is needed to obtain as much as possible inspirations and suggestions from the employees and managers on how the new motivation program should be aimed, what elements should become the parts of this program, in what way the organizational program should be transformed into the group/sectional and individualized programs, in what way these programs should be evaluated, etc. This implies a huge amount of communicated facts related to the quantitative and qualitative content, events, or elements. It is necessary to motivate employees and managers to be willing to communicate in this area and thus provide expected inspirations - communicate not only about the work but also about the opportunities that can improve its course and increase the feeling of joy from work done.

A key aim of such a broad conception of the link between communication and motivation is to achieve the state in which the quality of communication and informativeness will reasonably be resulted in permanent harmonizing all the motivations in the organization. Based on the cultivated communication, these motives must be harmonized inside the organization: motives of the employees with motives of the managers; motives of the individuals with motives of the group; motives of the groups with motives of the organization; contemporary motives with future motives; egoistic motives with social, altruistic motives; accelerative motives with dampening motives; shortterm motives with long-term motives, and so on. In other words, communication should be a means of connection of many motivations of many individuals and groups. Communication should be motivating; communication and its improvement should become the motivation. And, motivation and its contents must be communicated to others so that the individual motivations might become the common motivations.

\section{Acknowledgement}

Paper was conducted within the projects: VEGA 1/0890/14 Stochastic Modelling of Decision Making Processes in Motivating Human Potential and VEGA 1/0064/15 Competences Optimization in Correlative Relations with Specificities of Type Positions in Private Security. 


\section{References}

[1] BRATTON, J.: Introduction to Work and Organizational Behaviour, $3^{\text {rd }}$ ed., New York : Palgrave, 2015.

[2] ALDAG, R. J., KUZUHARA, L. W.: Creating High Performance Teams, New York : Routledge, 2015.

[3] SOKOL, A.: Management of a Creative Organization. Sokol, A. (ed.). Managing Diversity in the Organization, London : Sciencee Publishing, 2015, pp. 9-48.

[4] BLASKOVA, M., BLASKO, R., JANKALOVA, M., JANKAL, R.: Key Personality Competences of University Teacher: Comparison of Requirements Defined by Teachers and/versus Defined by Students. Procedia - Social and Behavioral Science, vol. 114, 2014, pp. 466-475. doi: 10.1016/j.sbspro.2013.12.731.

[5] VODAK, J., SOVIAR, J., LENDEL, V.: Identification of the Main Aspects of Cooperation Management and the Problems Arising from Their Misunderstanding. Communications - Scientific Letters of the University of Zilina, vol. 16, No. 3, 2014, pp. 93-101.

[6] KING, D., LAWLEY, S.: Organizational Behaviour, Oxford University Press, 2013.

[7] BYERS, P. Y.: Organizational Communication: Theory and Behavior, Boston : Allyn \& Bacon, 1997.

[8] FRANKEL, E. G.: Quality Decision Management - the Heart of Effective Futures-Oriented Management. Topics in Safety, Risk, Reliability and Quality, 14, 2008.

[9] PETERS, T. R., WATERMAN, R. H.: In Search of Excellence: Lessons from America's Best-Run Companies, New York : Harper and Row, 1982.

[10] TEPPER, B. B.: Managerial Knowledge and Skills (in Czech), Praha : Grada, 1996.

[11] BARRETT, R.: The Values-Driven Organization. New York: Routledge, 2014.

[12] MATUSKA, E.: Human Resources Management in a Modern Company, Gdynia : Wyzsza Szkola Adminsitracji i Biznesu im. Eugeniusza Kwiatkowskiego, 2014.

[13] URBAN, P.: Communication from the Expression Qualities System Perspective. Communications - Scientific Letters of the University of Zilina, vol. 16, No 3, 2014, pp. 51-55.

[14] VANATHAS, CH., JAMBULINGAMA, M., MATIAH, J.: Non-Verbal Communication and Satisfaction on the Banking Industry. International Business Management, vol. 10, No. 4, 2016, pp. 324-328. doi: 10.3923/ibm.2016.324.328.

[15] HOLA, J.: Internal Communication in a Company (in Czech), Brno : Computer, 2006.

[16] DABBISH, L., KRAUT, R. E.: Controlling Interruptions: Awareness Displays and Social Motivation for Coordination. Proc. of CSCW' 04 , New York, 2004.

[17] OWEN, J.: How to Manage, London : Pearson Education Ltd., 2006.

[18] TEGZE, O.: Non-verbal Communication (in Czech), Praha : Computer Press, 2003.

[19] MIKULASTIK, M.: Communication Skills in Practice, Praha : Grada Publishing, 2003.

[20] BUDA, B.: Empathy. Psychology of Empathizing and Taking on the Other (in Slovak), Nove Zamky : Psychoprof, 1994.

[21] TUBBS, S. L., MOSS, S.: Human Communication, $6^{\text {th }}$ ed., McGraw-Hill, 1991.

[22] BEDRNOVA, E., NOVY, I. et al.: Psychology and Sociology of Management (in Czech). $2^{\text {nd }}$ ed., Praha : Management Press, 2004.

[23] MAYFIELD, J., MAYFIELD, M., SHARBROUGH, W. C.: Strategic Vision and Values in Top Leaders' Communications: Motivating Language at a Higher Level. Intern. J. of Business Communication, vol. 52, No. 1, 2015, pp. 97-121.

[24] KACHANAKOVA, A., STACHOVA, K., STACHO, Z.: Organisational Culture Affects All Formalised Activities of Human Resources Management. Human Resources Management and Ergonomics, vol. 8, No. 2, 2014, pp. 61-71.

[25] FIGURSKA, I.: Knowledge Management in an Organization, Slupsk : HHS, 2012.

[26] SEDIKIDES, C., STRUBE, M. J.: Self-evaluation: To Thine Own Self Be Good, to Thine Own Self Be Sure to Thine Own Self Be True, and to Thine Own Self Be Better. Advances in Experimental Social Psychology, vol. 29, 1997, pp. 206-269.

[27] SILVIA, P. J., DUVAL, T. S.: Self-Awareness, Self-Motives, and Self-Motivation. Wright, R. A., Greenberg, J., Brehm, S. S. (eds.). Motivation and Emotion in Social Contexts: Jack Brehm's Diverse Influence on Contemporary Psychological Thought, Mahwah, NJ: Erlbaum, 2004. doi: 10.4324/9781410610089.

[28] EKMAN, P.: Emotional and Conversational Non-verbal Signals. Larrazabal, J. M., Miranda, L. (eds.). Language, Knowledge and Representation. Springer, 2004, pp. 39-50. 